\title{
Review
}

\section{Drama og skapende prosesser i barnehagen}

Edited by Anita Hammer and Guro Strømsøe.

Bergen: Fagbokforlaget, 2015, 211 p.

Reviewer: Ulrika von Schantz (Stockholm University)

Authenticity is regarded as an out-dated concept in postmodern times. Shakespeare's famous phrase "All the World is a Stage" seems more relevant than ever. We perform our lives on the internet, competing about "likes" in social media, constructing ourselves like fictional characters. We are wannabes searching for fame and glory in reality shows, trying to capture the glamorous lifestyle of music- , sport-, and movie stars. We play games with our selves as avatars and pretend to be what we are not to receive popularity on different sites. Simultaneously, as real life is conquered by virtual life, we live the ordinary lives of human beings with all their shortcomings. The intense interaction between reality and fiction makes it easy to get lost, even as an adult. How can adults working with young children be "authentic" and serve as positive role models in this world of theatrical games? How does one navigate between the fictional world out there and the real world here and now, and how can one learn to distinguish between good and bad, between play and dark play (without clear intentions and goals as well as frames and limits)? What can adults and children learn from each other and how? According to the authors in the book Drama og skapende prosesser $i$ barnehagen (Drama and creative 
processes in pre-school), 2015, the answer is as clear as it is congenial, referring to the theatrical character of the postmodern condition by using different forms of drama and theatre.

In this book, the editors Anita Hammer, professor of drama, and Guro Strømsøe, senior lecturer of drama, put forward the importance of art, culture and creativity in preschools. The purpose of the book is to fill a void within this area of knowledge as a response to the new guidelines for preschool education. As the title indicates, it particularly concerns creative processes in pedagogical work with drama and young children. Hence, the editors have gathered a group of authors, all of them experienced pedagogues, researchers, and/or theatre practitioners at Dronning Mauds Minne Høgskole (DMMH) in Trondheim, Norway, to discuss the impact of drama and theatre in preschools from different perspectives in the light of artistic practice.

The book offers some vital examples, in which pedagogues in preschool take part in the creative world of children's play by using aesthetic and communicative means. The examples underline the importance of playing with the children on their own terms, but within certain forms and specific frames. The reader is introduced to storytelling techniques, process drama, animation, puppet theatre, and theatre performances for and with children, involving various degrees of interaction. The key words are communication, presence, inter-action, fiction contract, and playing.

Drama and theatre is at the centre among the aesthetic subjects, since it includes elements from all the other art forms - music, visual art, storytelling, dance/movement etc., and as such it is characterized by a wide range of aesthetic activities and communicative perspectives. Because of its close connection to play and playing, and its multimodal, flexible character, the authors point to drama as most relevant in pedagogical work with children in preschool. "Children have 100 languages", to quote a well-known line from Loris Malaguzzi, the founder of Reggio Emilia, and multiple intelligences as Howard Gardner told us long ago. They also possess different learning styles. 
Throughout the book's nine chapters, each one based on various theoretical influences, the authors cover a number of core concepts in drama, i.e. improvisation and fiction, story-telling, process drama, dramaturgy, interactive performance, play and playing, aesthetic learning and aesthetic learning processes. Significant for the texts is the focus on inter-active processes rather than products, as well as on equality between children and pedagogues, mutual communication and attentive presence. The pedagogue is encouraged to capture the moment, to learn to listen more attentively, and to stimulate pedagogical inter-action with the children, where both parts serve simultaneously as listeners and actors. The aim is not only to raise consciousness about the responsibility one has as a pedagogue, but also to show how to develop so called "responsibility" (ability to respond), through aesthetic transformation of every day experiences. The different authors share a common emphasis on the necessity of arts-educated teachers and pedagogues in preschools.

Setting the agenda for the entire book in the first chapter, Anita Hammer focuses on the notion of performativity whereby she claims that people today increasingly live their every day lives performatively. She also points out the paradoxical situation of our growing use of theatrical means, while the theatre as an institution appears to be losing ground. Be that as it may, children seem to deal with the real world in a fictitious way through imagination and playing (Hammer prefers the notion of playing instead of play, since playing refers to the process). Children are actors and playwrights "by nature", Hammer claims. They decide on the characters that matter, they compose the story, and create the "stage". They switch between involvement and detachment in discussing how to perform the events. They learn by playing (and by doing), whether it is through fictive or real events. Children are also usually skilled improvisers as they compose stories as they go along, trying out various roles. Further on, when absorbed in the creative process, children appear to be postmodern "by nature", because they so easily pick up and combine fragments from all kinds of media: fairy tales, myths, TV-programs, movies, news, cartoons, etc. 
Having read this I expected the following chapters to involve posthuman theories, since it often occurs in recent Swedish research literature on preschool as well as in current teaching in Swedish early childhood education (at least at Stockholm University). In the latter case, children's playing is more or less expressed as "experimentation" and analysed through the lens of, for instance, Deleuze \& Guattari's notions of becoming, flight lines, etc. or Karen Barad's idea of intra-activity, where the world is made of entanglements of "social" and "natural" agencies. But instead, these authors are frequently referring to Norwegian drama practitioners/-theorists. Beside these, and among other references due to the specific subject in hand, the contributors (not only, and not all of them) basically lean on well-known theorists like John Dewey, Lev Vygotsky, Augusto Boal, and Aristotle. Against this background, the authors write about the work of children's play and playing in the name of democracy. The original and fundamental ambition of drama, where ethics and aesthetics are inseparable, namely to strengthen and promote democratic values - if not the fostering of democratic citizens - is obviously at stake here; drama and theatre are contrasted with dark play and other traps, inevitably belonging to the questionable character of communication in social media and on-line games.

Drama methods and different genres shift according to context, depending on a variety of aims and goals. When working with drama, playing is at stake, but with distinct "play frames", which makes the participants able to switch between involvement and distance, emotional experience and thoughtful reflection. Hence, drama should not be confused with children's free play(ing), though it includes play. Drama is a flexible but structured activity, planned by a pedagogue, supposed to reach certain goals. Subsequently Hammer - like all the other authors - underlines the importance and awareness of meta-communication. The interaction between involvement and distance, the oscillation between acting and spectating, stimulates reflection on several levels; a kind of aesthetic doubleness that in-creases the capability to be part of the fictional world and the real world at the same time, without the risk of confusing them. To that purpose, and in spite of - or because of - the post-modern character of children's 
playing, Hammer proposes Aristotle's drama theories, and points out the connection between theatre and rituals, referring to Victor Hugo and Richard Schechner. Whether the example is recognized as a discovery walk with children in the forest, a process drama in a museum concerning our cultural heritage, or a more or less interactive theatre performance, Hammer thereby claims the need of organisation within physical and narrative frames - the application of characters, plot, space, and time - and to put weight on symbolic objects (i.e. "transitional objects" to follow the psychologist Winnicott), like for instance animated toys, puppets and simple materials like paper or cloth, to facilitate the communication.

In the following eight chapters, each author - in his/her own way, and in dialogue with the other authors - takes or develops one or more of the perspectives set by Hammer. The texts mainly concern pedagogical work with preschool children whereby a number of the contributions focus on the very youngest children.

The main target group of the book is students in the field of early childhood education, but the book is also relevant for experienced teachers as well as researchers. As a senior lecturer in educational drama and theatre at Stockholm University, I regard the book an important and awaited contribution to the field. Drama and theatre in educational contexts are serious matters. As an educational and academic field, it needs to be constantly updated, evaluated and criticised, not least in the context of preschool and early childhood education. It is not unusual among drama practitioners to consider drama as a panacea for all problems; but we need no more 'preaching'. We seriously need to discuss our own shortcomings, mistakes and failures. It is interesting to read about how to benefit from a repertoire of drama exercises, and about the positive results from responsive communication. However, the main advantages of this book, whether we as readers are true believers or affected by doubts, are not the retold interesting examples of when and how certain things turned out successfully, but the nuanced depictions of the authors' own cases of shortcomings, mistakes and failures and what they learned from the children's reactions in 
these situations. An example is a disturbing moment in a storytellers show, when a girl is repeatedly interrupting, eager to know if the skirt in the story is pink, and the storyteller - who just wants to tell the story the ordinary cool way ignores her. But the girl is stubborn, and the storyteller feels forced to respond to her: Yes, it is pink. After a while he finds himself embroidering the story with details of the skirt and the girl looks happier and happier, simultaneously as the storyteller learned something about himself and the girl, as well as he got a better story... Significantly interesting are also the sharp observations of how a drama process may fail, when it is too rigidly scheduled and based on naive prejudices.

As the drama pioneer Dorothy Heathcote warned us already in the 1930's: drama could be abused like a horse (method) in front of any wagon (subject) at all, i.e. drama isn't a good thing "by itself" - in wrong hands it might serve improper issues. Drama is a strong medium, and good intentions easily turn out bad, if not mastered by experienced and empathic, skilled and educated pedagogues. 